\title{
Pembangunan Game Analysis Training terhadap Peningkatan Kemampuan Berpikir Induktif pada Siswa Tingkat SMP menggunakan Speech Recognition (Studi Kasus: SMPS YKPP Sungai Pakning)
}

\author{
Heri Sasmita $^{1 *}$, Wenda Novayani ${ }^{2 * *}$ \\ * Teknik Informatika, Politeknik Caltex Riau \\ ** Teknik Komputer, Politeknik Caltex Riau \\ heri16ti@mahasiswa.pcr.ac.id ${ }^{1}$,wenda@pcr.ac.id ${ }^{2}$
}

\begin{tabular}{l}
\hline Article Info \\
\hline Article history: \\
Received 2020-05-12 \\
Revised 2020-05-20 \\
Accepted 2020-06-08 \\
\hline
\end{tabular}

Keyword:

Android,

Berpikir Induktif,

Game Analysis Training,

Speech Recognition

\begin{abstract}
Penalaran induktif adalah cara menarik kesimpulan yang bersifat umum dari kasuskasus yang bersifat individual. Berpikir nalar matematis adalah salah satu kemampuan utama yang perlu dimiliki dan merupakan fitrah manusia. Penelitian ini menggunakan form Intelligenz Structure Test dan Inductive Reasoning Test dan telah diujikan kepada peserta didik dengan rentang usia 12-15 Tahun untuk melihat kemampuan berpikir induktif dari peserta didik yang diujikan. Sebelum melakukan pengujian, materi yang digunakan dalam game ini telah melewati tahapan validasi yang dilakukan oleh salah seorang psikolog klinis di Kota Pekanbaru. Hasil dari pengujian menyatakan bahwa pengujian yang dilakukan menggunakan metode game lebih baik daripada konvensional. Pernyataan ini dibantu dengan hasil pengujian pretest dan post-test yang telah dilakukan, di mana terjadi peningkatan pada hasil posttest menggunakan metode game dengan tingkat persentasi kebenaran sebesar 13,8\% untuk form Intelligenz Structure Test dan 8,28\% untuk form Inductive Reasoning Test.
\end{abstract}

\section{Pendahuluan}

\section{A. Latar Belakang}

Dari hasil wawancara langsung yang dilakukan dengan guru matematika di SMPS YKPP Sungai Pakning, mengungkapkan bahwa masih banyak peserta didik di sekolah yang memiliki pemahaman yang rendah mengenai pelajaran berhitung, terutama di pelajaran yang saat ini diajarinya, yaitu Matematika, hal ini disebabkan oleh kurangnya minat dan pemahaman peserta didik dengan pelajaran Matematika. Selain itu, banyak siswa-siswi yang sulit melakukan penalaran terhadap soal-soal yang diberikan di sekolah, sehingga siswa-siswi selalu kebingungan ketika membaca soal dan tidak tahu apa maksud dari soal yang diberikan. Maka jika hal ini terus dibiarkan, maka akan berpengaruh pada nilai akademik siswa-siswi didikannya.

Melalui berpikir nalar, manusia terus berkembang dan meningkatkan kemampuan dalam beradaptasi dengan lingkungan yang dinamis dan berubah secara kontinu serta dapat berkreasi dan menciptakan teknologi yang dapat mempermudah kehidupannya. Manusia selalu berpikir serta melalui daya nalarnya dapat membedakan argumen yang valid maupun invalid [1]

Melalui permasalahan yang ditemukan, penulis langsung melakukan awancara langsung dengan seorang psikolog klinis yang ada di Pekanbaru. Menurutnya, kurangnya kemampuan menganalisis suatu permasalahan dapat membuat manusia tidak mandiri dalam menyelesaikan suatu masalah, dimana kemampuan analisis dalam penyelesaian suatu masalah merupakan hal yang sangat penting dalam membentuk manusia yang berkarakter dewasa. Oleh sebab itu, maka dibangun sebuah game analysis untuk meningkatkan kemampuan berpikir induktif dengan mengacu pada form Inductive Reasoning Test dan form Intelligenz Structure Test subtest Zahlen Reihen untuk menguji kemampuan berpikir induktif siswa. Kemudian psikolog dan guru matematika juga menuturkan bahwa dengan adanya pembangunan game ini, maka kemampuan berpikir induktif dapat diterapkan kepada siswa-siswi di sekolah, hal ini dikarenakan game merupakan sebuah media yang disukai oleh anak serta menjadi media yang baik, interaktif dan efektif untuk proses pembelajaran anak.[2] 
Selain itu, seperti pengertiannya bahwa game adalah sebuah sistem yang memiliki kumpulan aturan-aturan buatan yang melibatkan pemain dengan tujuan untuk menghibur. Game berisikan skenario yang tersusun dari kumpulan audio dan visual yang menarik, sehingga membuat pemain dapat menikmati jalannya permainan yang disajikan pada game tersebut [3].

Untuk saat ini, terdapat media yang sudah yakni Rancang Bangun Game Berhitung Spaceship dengan Pengendali Suara Menggunakan Speech Recognition Plugin pada Unity [4], Kemudian Penerapan Speech Recognition pada Permainan Teka-Teki Silang Menggunakan Metode Hidden Markov Model (HMM) [5], Kemudian game untuk membantu meningkatkan kemampuan mengingat siswa SMP, yaitu game Short Term Memory (STM) [6], kemudian game untuk meningkatkan kemampuan Analysis, yang mengacu pada form Wechsler-bellevue [7]. Game yang dibangun menggunakan genre educational game. Genre game didefinisikan sebagai karakteristik permainan yang ditandai dengan kesamaan gaya, konten, dan gameplay. Dengan mendefinisikan genre dan mengelompokkan permainan, pendidik akan memiliki lebih banyak pilihan untuk mengintegrasikan permainan ke dalam tujuan pembelajaran [8].

Penjelasan-penjelasan diatas menjadi dasar dari penelitian ini yakni membangun sebuah game pembelajaran berbasis Android menggunakan aplikasi Unity bagi siswa-siswi SMPS YKPP Sungai Pakning dalam meningkatkan kemampuan berpikir induktif. Permainan akan dibangun menggunakan Intelligenz Structure Test (IST) sub-test ZR (Zahlen Reihen) dan Inductive Reasoning Test, dimana pada game ini akan diberikan soal berbentuk deretan numerik dan gambar menggunakan pola tertentu, kemudian anak akan mengisinya dengan melanjutkan pola deretan selanjutnya. Dengan begitu, pola pikir induktif anak dalam berhitung dan menalar dapat terasah dengan menggunakan media interaktif tersebut.

Berdasarkan latar belakang yang sudah dituliskan, maka dapat dirumuskan permasalahan yakni bagaimana membangun sebuah game yang menarik untuk dapat meningkatkan kemampuan berpikir induktif pada siswa tingkat SMP.

\section{Metode Penelitian}

Metode penelitian yang dilakukan dalam pembuatan penelitian ini adalah sebagai berikut.

\section{1) Blackbox Testing}

Black-Box Testing merupakan pengujian yang berfokus pada spesifikasi fungsional dari perangkat lunak, tester dapat mendefinisikan kumpulan kondisi input dan melakukan pengetesan pada spesifikasi fungsional program [9].

Blackbox testing dilakukan oleh psikolog klinis, pengujian ini dilakukan untuk memastikan fungsi-fungsi dalam aplikasi dapat berjalan dengan baik dan menampilkan output sesuai dengan yang diharapkan Setiap fungsi yang ada pada aplikasi dituliskan kedalam tabel testcase, lalu diujikan sesuai dengan scenario game. Fungsi yang berhasil dijalankan ditandai dengan keterangan "valid". Sementara itu fungsi yang tidak dapat berjalan dengan baik diberi tanda "tidak valid". Adapun kolom komentar yang digunakan untuk mencatat keterangan apabila terdapat fungsi yang tidak berjalan sesuai dengan apa yang diharapkan.

Tahapan yang dilakukan pada Black Box testing ini adalah menguji satu per satu fungsi-fungsi yang terdapat pada game analysis training dan memastikan semua berjalan dengan baik berupa kesesuaian tampilan ataupun output ketika game dijalankan sesuai dengan yang diharapkan.

\section{2) Validasi Konten}

Validasi konten game analysis training dilakukan oleh psikolog klinis, bahwa game yang dibangun dapat membantu meningkatkan kemampuan siswa dalam menganalisis soal karena pada game ini siswa diminta untuk memikirkan apa kelanjutan dari suatu pola dari deret angka atau deret gambar yang diberikan. Kemudian game diuji kembali sesuai dengan ketentuan form Intelligenz Structure Test dan form Inductive Reasoning Test.

Tahapan pengujian validasi diawali dengan melakukan pengecekan apakah soal-soal yang ditampilkan pada game analysis training sudah sesuai dengan aturan psikologi. Kemudian setelah melakukan pemeriksaan kesesuaian soal, dilakukan lagi pengecekan tingkat kesulitan soal sesuai dengan usia anak 12-15 tahun. Kemudian setelah dua hal tersebut sudah sesuai, maka dilakukan pengecekan selanjutnya yaitu memeriksa score pada setiap soal dan menyesuaikannya dengan aturan psikologi.

Berikut ini merupakan Tabel Skor untuk form Intelligenz Structure Test

TABEL I

ROW SCORE INTELLIGENZ STRUCTURE TEST

\begin{tabular}{|c|c|c|c|}
\hline $\begin{array}{l}\text { Row } \\
\text { Score }\end{array}$ & $\begin{array}{l}\text { Intelligenz } \\
\text { Structure Test }\end{array}$ & Row Score & $\begin{array}{l}\text { Intelligenz } \\
\text { Structure Test }\end{array}$ \\
\hline 0 & 79 & 11 & 105 \\
\hline 1 & 81 & 12 & 107 \\
\hline 2 & 84 & 13 & 109 \\
\hline 3 & 85 & 14 & 112 \\
\hline 4 & 88 & 15 & 114 \\
\hline 5 & 91 & 16 & 116 \\
\hline 6 & 93 & 17 & 119 \\
\hline 7 & 95 & 18 & 121 \\
\hline 8 & 98 & 19 & 123 \\
\hline 9 & 100 & 20 & 126 \\
\hline 10 & 102 & & \\
\hline
\end{tabular}

Berikut ini merupakan Tabel Skor untuk form Inductive Reasoning Test [10]

TABEL II

ROW SCORE INDUCTIVE REASONING TEST

\begin{tabular}{|c|l|c|c|}
\hline $\begin{array}{l}\text { Row } \\
\text { Score }\end{array}$ & $\begin{array}{l}\text { Inductive } \\
\text { Reasoning Test }\end{array}$ & Row Score & $\begin{array}{l}\text { Inductive } \\
\text { Reasoning Test }\end{array}$ \\
\hline 0 & 71 & 15 & 101 \\
\hline 1 & 73 & 16 & 103 \\
\hline
\end{tabular}




\begin{tabular}{|c|c|c|c|}
\hline 2 & 75 & 17 & 105 \\
\hline 3 & 77 & 18 & 107 \\
\hline 4 & 79 & 19 & 109 \\
\hline 5 & 81 & 20 & 111 \\
\hline 6 & 83 & 21 & 113 \\
\hline 7 & 85 & 22 & 115 \\
\hline 8 & 87 & 23 & 117 \\
\hline 9 & 89 & 24 & 119 \\
\hline 10 & 91 & 25 & 121 \\
\hline 11 & 93 & 26 & 123 \\
\hline 12 & 95 & 27 & 125 \\
\hline 13 & 97 & 28 & 127 \\
\hline 14 & 99 & 29 & 129 \\
\hline & & 30 & 131 \\
\hline
\end{tabular}

\section{3) Pengujian Speech Recognition}

Teknologi speech recognition merupakan teknologi pengenalan wicara yang memanfaatkan sinyal suara manusia sebagai masukan untuk kemudian dikenali oleh system komputer. Teknologi ini merupakan pengembangan interaksi antara manusia dengan komputer untuk meminimalisir peralatan inputdevice seperti mouse, keyboard maupun peralatan interface lainnya [11].

\section{4) Experiment Design}

Pengujian ini dilakukan kepada siswa-siswi SMPS YKPP Sungai Pakning yang sebanyak 2 kelas, yakni kelas IX C dan IX B. Yang masing-masing terdiri dari 25 siswa. Pengujian tahapan pertama adalah dengan melakukan pengujian menggunakan metode konvensional kepada siswa-siswi kelas IX C dimana siswa-siswi diberikan pretest terlebih dahulu kemudian diberikan pengajaran melalui penjelasan oleh Ibu Kasmawati melalui buku dan memberikan contoh melalui papan tulis selama 15 menit sebelum kemudian dilakukan post-test menggunakan metode konvensional (kertas).

Berikut ini merupakan gambaran pelaksanaan experiment design pada siswa/I SMPS YKPP Sungai Pakning:

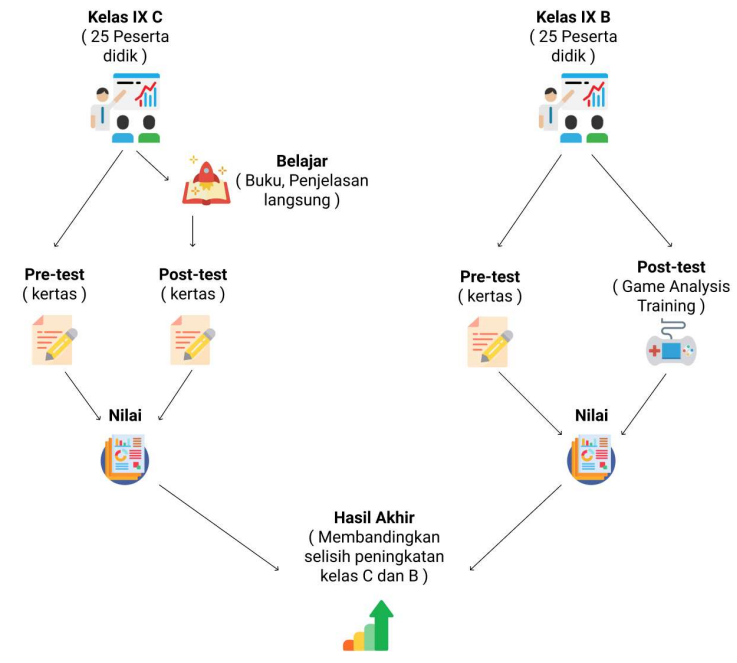

Gambar 1. Gambaran Pelaksanaan Experiment Design
Gambar 1 merupakan gambaran pelaksanaan pengujian experiment design, pengujian dilakukan kepada dua kelas, yakni kelas IX C dan IX B yang masing-masing terdiri dari 25 siswa. Pengujian tahap pertama dilakukan dengan memberikan pretest pada masing-masing kelas dengan batas waktu selama 15 menit. Kemudian kelas IX C diberikan penjelasan berupa pengajaran yang dilakukan menggunakan media buku dan penjelasan langsung kemudian dilakukan post test. Sedangkan kelas IX B langsung diberikan post test menggunakan Game Analysis Training. Setelah kedua kelas selesai melakukan post test, maka hasil akhir nya adalah melakukan perbandingan skor yang didapatkan melalui dua kelas tersebut.

\section{Analisis dan Perancangan}

\section{A. Analisis Validasi Konten}

Validasi konten game analysis training dilakukan oleh psikolog klinis, bahwa game yang dibangun dapat membantu meningkarkan kemampuan siswa dalam menganalisis soal karena pada game ini siswa diminta untuk memikirkan apa kelanjutan dari suatu pola dari deret angka atau deret gambar yang diberikan. Kemudian game diuji kembali sesuai dengan ketentuan form Intelligenz Structure Test dan form Inductive Reasoning Test. Kemudian setelah melakukan Validasi konten, dinyatakan bahwa soal-soal yang disajikan telah valid sesuai dengan ketentuan dari bidang psikologi.

\section{B. Analisis Blackbox Testing}

Black Box testing dilakukan psikolog klinis, pengujian ini dilakukan untuk memastikan fungsi-fungsi dalam aplikasi dapat berjalan dengan baik dan menampilkan output sesuai dengan yang diharapkan Setiap fungsi yang ada pada aplikasi dituliskan kedalam tabel testcase, lalu diujikan sesuai dengan scenario game. Fungsi yang berhasil dijalankan ditandai dengan keterangan "valid". Sementara itu fungsi yang tidak dapat berjalan dengan baik diberi tanda "tidak valid". Adapun kolom komentar yang digunakan untuk mencatat keterangan apabila terdapat fungsi yang tidak berjalan sesuai dengan apa yang diharapkan.

\section{Use Case Diagram}

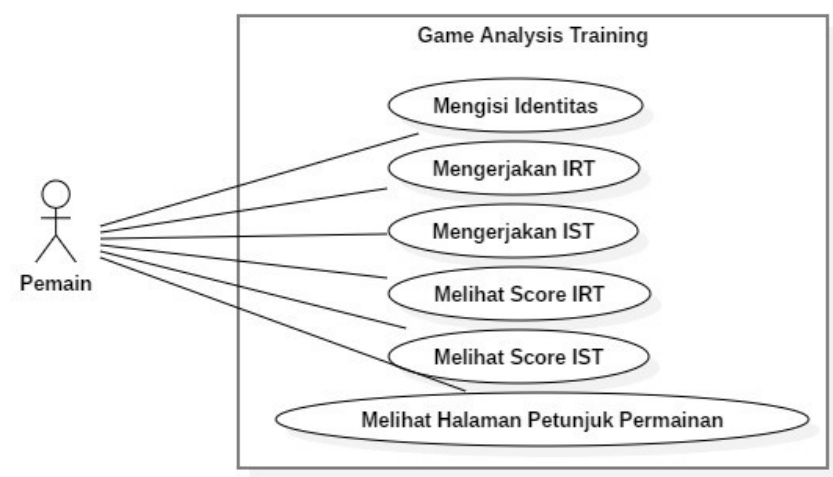

Gambar 2. Use Case Game Analysis Training. 
Gambar 2 menjelaskan bahwa pada aplikasi ini, pengguna dapat melakukan beberapa aktivitas seperti mengisi data identitas pemain berupa nama, mengerjakan test Intelligenz Structure Test dan Inductive Reasoning Test, Melihat Score Intelligenz Structure Test dan Inductive Reasoning Test, dan melihat halaman petunjuk permainan.

\section{D) Sequence Diagram}

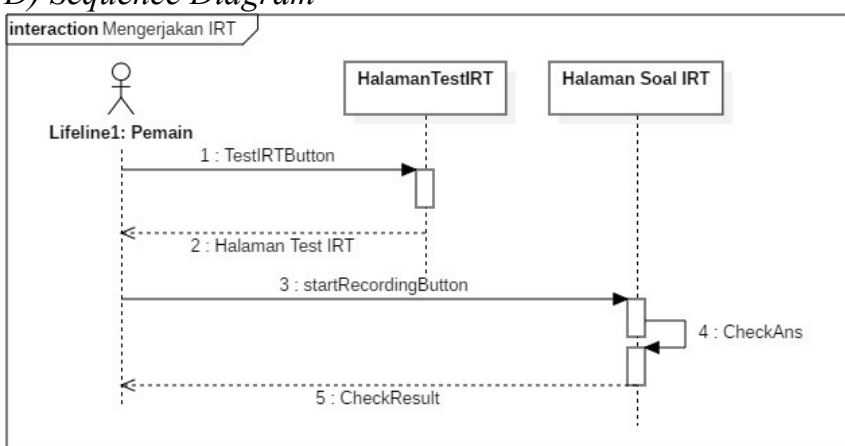

Gambar 3. Sequence Diagram Mengerjakan Inductive Reasoning Test

Gambar 3 menjelaskan proses yang terjadi ketika pemain melakukan test Inductive Reasoning Test, Saat pemain membuka halaman test, maka akan diberikan feedback berupa tampilan halaman soal, dan Ketika pemain menjawab menggunakan speech recognition atau pilihan tombol, maka aplikasi akan melakukan pengecekan jawaban dan diberikan hasil yang akan ditampilkan pada saat setelah pemain mengisi seluruh soal yang ada pada form tersebut.

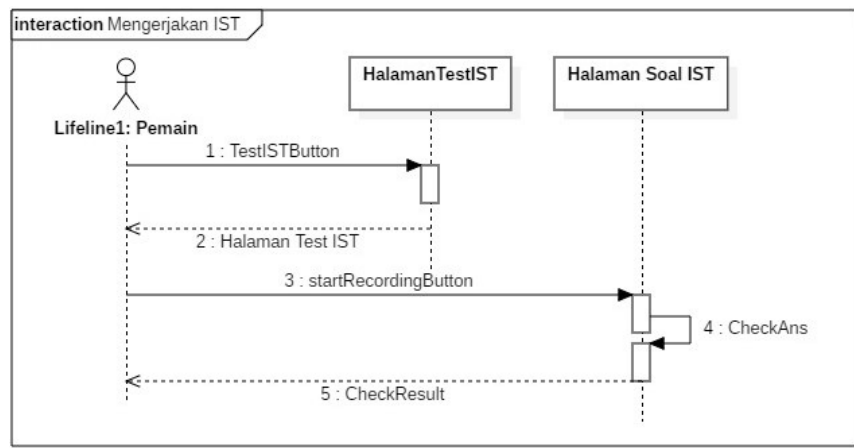

Gambar 4. Sequence Diagram Mengerjakan Intelligenz Structure Test

Gambar 4 menjelaskan proses yang terjadi ketika pemain melakukan test Intelligenz Structure Test, Saat pemain membuka halaman test, maka akan diberikan feedback berupa tampilan halaman soal, dan Ketika pemain menjawab menggunakan speech recognition atau pilihan tombol, maka aplikasi akan melakukan pengecekan jawaban dan diberikan hasil yang akan ditampilkan pada saat setelah pemain mengisi seluruh soal yang ada pada form tersebut.

\section{Hasil dan PEMbahasan}

A. Hasil Pembangunan Game Analysis Training

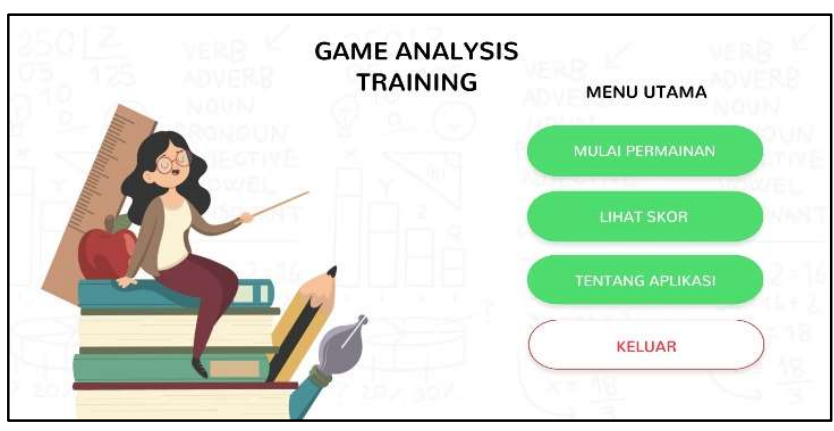

Gambar 5. Halaman Menu Game Analysis Training.

Gambar 5 menjelaskan bahwa pada saat awal pemain telah mengisi data diri dan menekan tombol mulai, maka akan ditampilkan halaman menu game yang terdiri dari tombol "Mulai Permainan", "Lihat Score", "Tentang Aplikasi", dan "Keluar". Ketika pemain menekan tombol Mulai permainan, maka akan pindah ke halaman menu pilihan berupa test yang tersedia, yakni Intelligenz Structure Test dan Inductive Reasoning Test. Apabila menekan tombol Lihat Score, maka akan pindah ke halaman skor yang terdiri dari skor Intelligenz Structure Test dan Inductive Reasoning Test. Begitu pula pada tombol Tentang Aplikasi, yang akan menampilkan halaman berupa informasi cara bermain game analysis training.

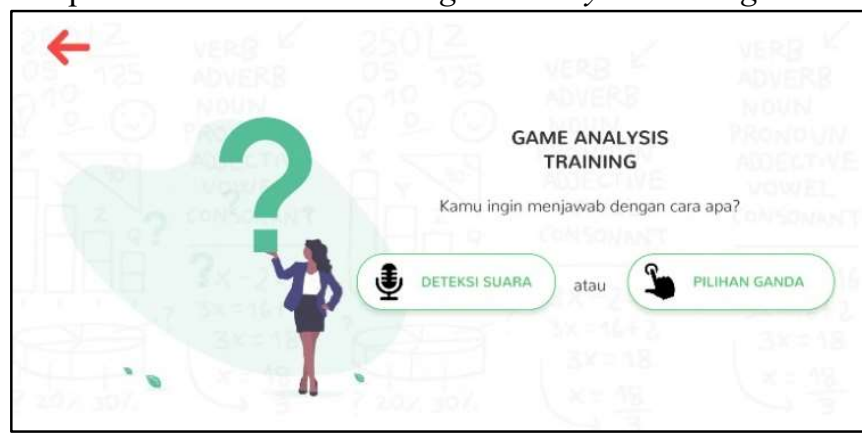

Gambar 6. Halaman Metode menjawab Game Analysis Training.

Gambar 6 menjelaskan bahwa pada saat Pemain memilih salah satu form, maka akan memunculkan halaman metode menjawab, pemain bisa memilih ingin menjawab menggunakan speech recognition ataupun menggunakan tombol pilihan.

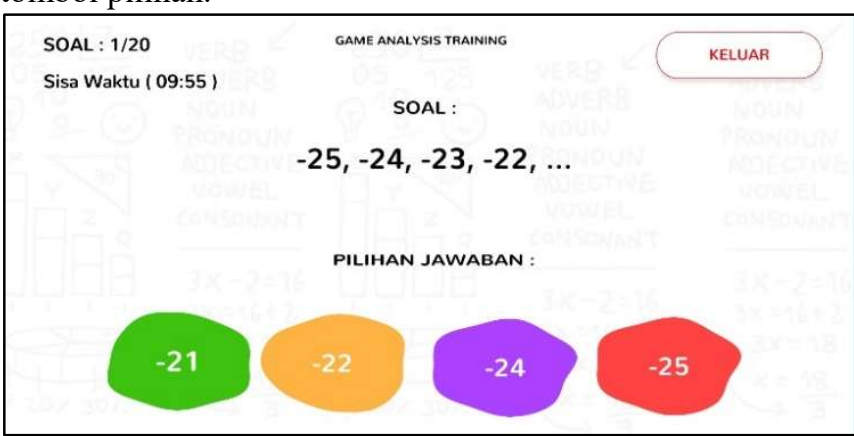

Gambar 7. Halaman Metode Tombol Game Analysis Training. 
Pada gambar 7 dijelaskan bahwa tampilan metode menjawab bagi pemain yang memilih metode tombol. Disediakan 4 pilihan tombol yang akan menjadi pilihan bagi pemain untuk memberikan jawaban.

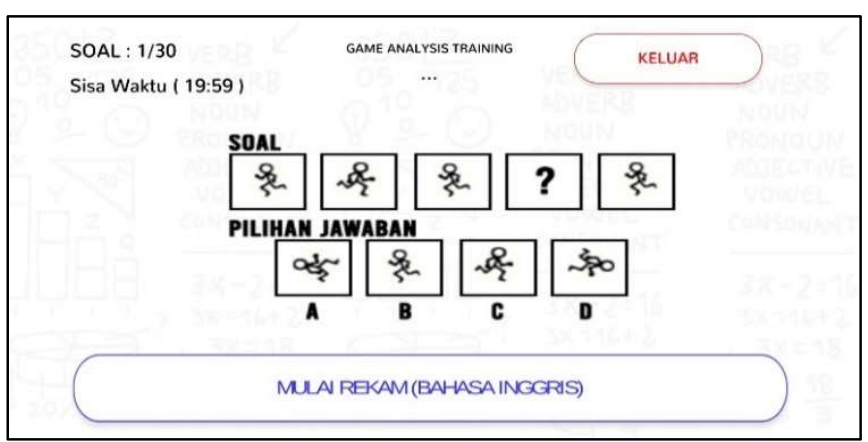

Gambar 8. Halaman Metode Suara Game Analysis Training.

Berikut ini merupakan tampilan halaman apabila pemain memilih metode menjawab menggunakan speech recognition. Pada halaman ini pemain harus menjawab dengan menyebutkan "huruf" atau "angka" untuk menjawab pertanyaan dan menggunakan Bahasa inggris.

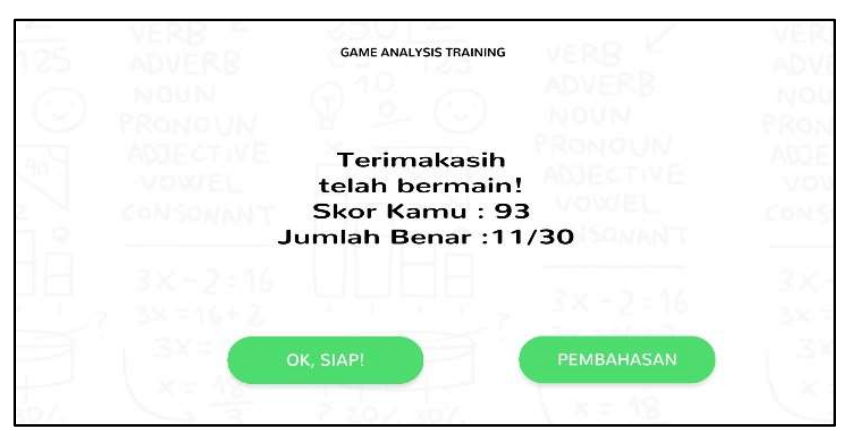

Gambar 9. Halaman Hasil Permainan Game Analysis Training.

Pada gambar 9 dijelaskan bahwa saat pemain sudah selesai mengisi semua soal yang terdapat pada tes yang diambil, game analysis training akan menampilkan hasil permainan yang telah dilakukan. Pemeriksaan jawaban yang dilakukan oleh pemain, secara otomatis ditampung pada data cache dan apabila jawaban yang diberi oleh pemain adalah "benar", maka akan dijumlahkan berdasarkan score yang telah ditentukan pada aplikasi. Pemain juga dapat memilih opsi pembahasan untuk memeriksa jawaban yang salah ataupun yang benar.

\section{B. Analisa Pengujian Experiment Design}

Pengujian ini dilakukan kepada siswa-siswi SMPS YKPP Sungai Pakning yang sebanyak 2 kelas, yakni kelas IX C dan IX B. Yang masing-masing terdiri dari 25 siswa. Pengujian tahapan pertama adalah dengan melakukan pengujian menggunakan metode konvensional kepada siswa-siswi kelas IX C dimana siswa-siswi diberikan pretest terlebih dahulu kemudian diberikan pengajaran melalui penjelasan oleh Ibu Kasmawati melalui buku dan memberikan contoh melalui papan tulis selama 15 menit sebelum kemudian dilakukan post-test menggunakan metode konvensional (kertas).

Berikut ini merupakan rincian nilai yang didapatkan dari 25 siswa-siswi kelas IX C terkait pengujian experiment design (pretest + post test):

TABEL III

PENGUJIAN IST IX C

\begin{tabular}{|c|l|c|c|c|}
\hline \multirow{2}{*}{ No. } & \multirow{2}{*}{ Nama Siswa } & \multicolumn{3}{|c|}{ Intelligenz Structure Test } \\
\cline { 3 - 5 } & & Pre-test & Post Test & Status \\
\hline 1 & M. Mahdi A. S & 50 & 55 & Meningkat \\
\hline 2 & Nurti S.R M & 85 & 95 & Meningkat \\
\hline 3 & Dhiya Sutrina & 25 & 55 & Meningkat \\
\hline 4 & Firman Anwar & 95 & 85 & Menurun \\
\hline 5 & Widya Zikra Fajry & 45 & 50 & Meningkat \\
\hline 6 & Nabila Falia A & 75 & 50 & Menurun \\
\hline 7 & Fatia Nurhafiza & 35 & 30 & Menurun \\
\hline 8 & Nova Agustin & 45 & 75 & Meningkat \\
\hline 9 & Arini Anugrah & 70 & 60 & Menurun \\
\hline 10 & Cynthia Juliani & 45 & 65 & Meningkat \\
\hline 11 & Yosua Firnando & 5 & 50 & Meningkat \\
\hline 12 & Cindy Oktania L & 30 & 60 & Meningkat \\
\hline 13 & Hady Dhia Sahda & 40 & 50 & Meningkat \\
\hline 14 & M. Ferdiansyah & 90 & 80 & Menurun \\
\hline 15 & Said Bagas D & 75 & 85 & Meningkat \\
\hline 16 & M. Galih Haikal F & 100 & 80 & Menurun \\
\hline 17 & Marvin Chandra & 95 & 100 & Meningkat \\
\hline 18 & Gilbert & 75 & 80 & Meningkat \\
\hline 19 & Hendra Siswanto & 60 & 65 & Meningkat \\
\hline 20 & Veny Deakristina & 65 & 65 & Tetap \\
\hline 21 & Clara Anggita & 45 & 50 & Meningkat \\
\hline 22 & Rafael Manalu & 60 & 55 & Menurun \\
\hline 23 & Ilham Genta A & 70 & 70 & Tetap \\
\hline 24 & Adrian & 80 & 80 & Tetap \\
\hline 25 & M. Rivan Juliadi & 80 & 85 & Meningkat \\
\hline & Rata-Rata & 61,6 & 67 & \\
\hline & & & & \\
\hline
\end{tabular}

TABEL IV

PENGUJian IRT IX C

\begin{tabular}{|c|l|c|c|c|}
\hline \multirow{2}{*}{ No. } & \multirow{2}{*}{ Nama Siswa } & \multicolumn{3}{|c|}{ Inductive Reasoning Test } \\
\cline { 3 - 5 } & & Pre-test & Post Test & Status \\
\hline 1 & M. Mahdi A. S & 33 & 51 & Meningkat \\
\hline 2 & Nurti S.R M & 69 & 72 & Meningkat \\
\hline 3 & Dhiya Sutrina & 45 & 48 & Meningkat \\
\hline 4 & Firman Anwar & 72 & 69 & Menurun \\
\hline 5 & Widya Zikra Fajry & 81 & 75 & Menurun \\
\hline 6 & Nabila Falia A & 54 & 57 & Meningkat \\
\hline 7 & Fatia Nurhafiza & 39 & 48 & Meningkat \\
\hline 8 & Nova Agustin & 78 & 84 & Meningkat \\
\hline 9 & Arini Anugrah & 66 & 63 & Menurun \\
\hline 10 & Cynthia Juliani & 78 & 66 & Menurun \\
\hline 11 & Yosua Firnando & 54 & 57 & Meningkat \\
\hline 12 & Cindy Oktania L & 57 & 57 & Tetap \\
\hline 13 & Hady Dhia Sahda & 66 & 69 & Meningkat \\
\hline 14 & M. Ferdiansyah & 63 & 78 & Meningkat \\
\hline 15 & Said Bagas D & 69 & 72 & Meningkat \\
\hline 16 & M. Galih Haikal F & 78 & 72 & Menurun \\
\hline 17 & Marvin Chandra & 81 & 81 & Tetap \\
\hline 18 & Gilbert & 57 & 57 & Tetap \\
\hline
\end{tabular}




\begin{tabular}{|c|l|c|c|c|}
\hline 19 & Hendra Siswanto & 60 & 72 & Meningkat \\
\hline 20 & Veny Deakristina & 60 & 75 & Meningkat \\
\hline 21 & Clara Anggita & 54 & 54 & Tetap \\
\hline 22 & Rafael Manalu & 36 & 36 & Tetap \\
\hline 23 & Ilham Genta A & 27 & 45 & Meningkat \\
\hline 24 & Adrian & 39 & 48 & Meningkat \\
\hline 25 & M. Rivan Juliadi & 54 & 57 & Meningkat \\
\hline \multicolumn{2}{|l|}{ Rata-Rata } & 58,8 & 62,52 & \\
\hline
\end{tabular}

Pada tabel III dan IV, dijelaskan perbandingan hasil tes IST dan IRT kepada siswa kelas IX C. rata-rata dari kelas tersebut adalah terjadinya peningkatan, namun persentase peningkatan pada kelas IX C jika dikalkulasikan, untuk jenis IST hanya mengalami peningkatan sebesar $5,4 \%$ dan jenis IRT mengalami peningkatan sebesar 3,72\%. Hal ini berbeda ketika Tes dilakukan pada kelas IX B yang akan ditampilkan pada tabel IV.

TABEL V

Pengujian IST Kelas IX B

\begin{tabular}{|c|l|c|c|c|}
\hline \multirow{2}{*}{ No. } & \multirow{2}{*}{ Nama Siswa } & \multicolumn{3}{|c|}{ Intelligenz Structure Test } \\
\cline { 3 - 5 } & & Pre-test & Post Test & Status \\
\hline 1 & A Abdurrachman & 30 & 80 & Meningkat \\
\hline 2 & Alrazelva Agdini & 65 & 65 & Tetap \\
\hline 3 & Khayla Salsabila & 65 & 70 & Meningkat \\
\hline 4 & Cut Alyssa & 60 & 90 & Meningkat \\
\hline 5 & Malika Shafira A & 80 & 80 & Tetap \\
\hline 6 & Lidya Fatyanda & 65 & 95 & Meningkat \\
\hline 7 & Ratna Dwi Juwita & 70 & 95 & Meningkat \\
\hline 8 & M. Chevio R & 50 & 60 & Meningkat \\
\hline 9 & M. Adib & 50 & 80 & Meningkat \\
\hline 10 & M. Yunus Yasin & 45 & 70 & Meningkat \\
\hline 11 & M. Fathurriansyah & 25 & 75 & Meningkat \\
\hline 12 & Putri Rahma R & 70 & 85 & Meningkat \\
\hline 13 & Naina Bilbhina S & 45 & 70 & Meningkat \\
\hline 14 & Sepri Winardi & 75 & 100 & Meningkat \\
\hline 15 & Andri Kurniawan & 75 & 40 & Menurun \\
\hline 16 & Nashwa Alya R & 50 & 45 & Menurun \\
\hline 17 & Charless Lee & 95 & 95 & Tetap \\
\hline 18 & Nur Atika Safitri & 75 & 70 & Menurun \\
\hline 19 & Rudy Handoko & 95 & 100 & Meningkat \\
\hline 20 & Ilham Sunami & 65 & 85 & Meningkat \\
\hline 21 & Kharisma Eko S & 65 & 65 & Tetap \\
\hline 22 & Nur Nada N & 70 & 80 & Meningkat \\
\hline 23 & Rasihan Yusri M & 40 & 60 & Meningkat \\
\hline 24 & Raditya Ramadhan & 50 & 55 & Meningkat \\
\hline 25 & Selina & 85 & 95 & Meningkat \\
\hline & Rata-Rata & 62,4 & 76,2 & \\
\hline & & & & \\
\hline
\end{tabular}

TABEL VI

PENGUJian IRT Kelas IX B

\begin{tabular}{|c|c|c|c|c|}
\hline \multirow{2}{*}{ No. } & \multirow{2}{*}{ Nama Siswa } & \multicolumn{3}{|c|}{ Inductive Reasoning Test } \\
\cline { 3 - 5 } & & Pre-test & Post Test & Status \\
\hline 1 & A Abdurrachman & 75 & 81 & Meningkat \\
\hline 2 & Alrazelva Agdini & 54 & 69 & Meningkat \\
\hline 3 & Khayla Salsabila & 66 & 81 & Meningkat \\
\hline
\end{tabular}

\begin{tabular}{|c|l|c|c|c|}
\hline 4 & Cut Alyssa & 30 & 60 & Meningkat \\
\hline 5 & Malika Shafira A & 75 & 75 & Tetap \\
\hline 6 & Lidya Fatyanda & 60 & 54 & Menurun \\
\hline 7 & Ratna Dwi Juwita & 51 & 57 & Meningkat \\
\hline 8 & M. Chevio R & 42 & 60 & Meningkat \\
\hline 9 & M. Adib & 72 & 81 & Meningkat \\
\hline 10 & M. Yunus Yasin & 33 & 30 & Menurun \\
\hline 11 & M. Fathurriansyah & 51 & 51 & Tetap \\
\hline 12 & Putri Rahma R & 63 & 72 & Meningkat \\
\hline 13 & Naina Bilbhina S & 51 & 60 & Meningkat \\
\hline 14 & Sepri Winardi & 66 & 66 & Tetap \\
\hline 15 & Andri Kurniawan & 45 & 63 & Meningkat \\
\hline 16 & Nashwa Alya R & 78 & 87 & Meningkat \\
\hline 17 & Charless Lee & 72 & 84 & Meningkat \\
\hline 18 & Nur Atika Safitri & 42 & 60 & Meningkat \\
\hline 19 & Rudy Handoko & 81 & 81 & Tetap \\
\hline 20 & Ilham Sunami & 39 & 57 & Meningkat \\
\hline 21 & Kharisma Eko S & 48 & 48 & Tetap \\
\hline 22 & Nur Nada N & 33 & 30 & Menurun \\
\hline 23 & Rasihan Yusri M & 42 & 33 & Menurun \\
\hline 24 & Raditya Ramadhan & 39 & 51 & Meningkat \\
\hline 25 & Selina & 36 & 60 & Meningkat \\
\hline & Rata-Rata & 53,76 & 62,04 & \\
\hline & & & & \\
\hline
\end{tabular}

Pada table V dan VI, dijelaskan perbandingan hasil tes IST dan IRT kepasa siswa kelas IX B. rata-rata dari kelas tersebut adalah terjadinya peningkatan, namun persentase peningkatan pada kelas IX B jika dikalkulasikan, untuk jenis IST mengalami peningkatan sebesar $13,8 \%$ dan jenis IRT mengalami peningkatan sebesar $8,28 \%$.

Dari hasil tes yang dilakukan, terdapat beberapa siswa yang mengalami penurunan nilai saat membandingkan nilai hasil pretest dan post-test, hal ini disebabkan oleh soal yang ditampilkan pada saat bermain game, mengalami pengacakan soal (random) sehingga siswa mendapatkan beberapa soal yang tidak dapat dikerjakan olehnya. selain itu, hal yang menjadi penyebab menurunnya nilai adalah kurang konsentrasinya peserta didik dalam menjawab persoalan yang ditampilkan, sehingga mengalami salah jawab dan membuat nilainya menjadi turun.

\section{Analisis Validasi Konten}

Validasi konten game analysis training dilakukan oleh psikolog klinis, bahwa game yang dibangun dapat membantu meningkatkan kemampuan siswa dalam menganalisis soal karena pada game ini siswa diminta untuk memikirkan apa kelanjutan dari suatu pola dari deret angka atau deret gambar yang diberikan. Kemudian game diuji kembali sesuai dengan ketentuan form Intelligenz Structure Test dan form Inductive Reasoning Test. Kemudian setelah melakukan Validasi konten, dinyatakan bahwa soal-soal yang disajikan telah valid sesuai dengan ketentuan dari bidang psikologi.

\section{Analisis Blackbox Testing}

Blackbox testing dilakukan oleh psikolog klinis, pengujian ini dilakukan untuk memastikan fungsi-fungsi dalam aplikasi dapat berjalan dengan baik dan menampilkan output sesuai 
dengan yang diharapkan Setiap fungsi yang ada pada aplikasi dituliskan kedalam tabel testcase, lalu diujikan sesuai dengan scenario game. Fungsi yang berhasil dijalankan ditandai dengan keterangan "valid". Sementara itu fungsi yang tidak dapat berjalan dengan baik diberi tanda "tidak valid". Adapun kolom komentar yang digunakan untuk mencatat keterangan apabila terdapat fungsi yang tidak berjalan sesuai dengan apa yang diharapkan.

\section{E. Analisis Speech Recognition}

Analisis ini dilakukan dengan melalukan percobaan spelling untuk menentukan apakah pengucapan yang dilakukan ketika memainkan Game Analysis Training dapat berjalan dengan baik dan benar. Adapun sample yang diambil dalam mengujikan spelling dari speech recognition pada game ini:

TABEL VII

Pengujian SPeECh ReCOGNition HuruF

\begin{tabular}{|c|c|}
\hline Pengucapan & Keterangan \\
\hline A & Valid \\
\hline B & Valid \\
\hline C & Valid \\
\hline D & Valid \\
\hline
\end{tabular}

Kemudian pengujian speech recognition ini juga dilakukan berupa penyebutan angka. Pengujian ini dilakukan untuk menentukan apakah penyebutan angka secara langsung juga valid dan tepat ketika dicobakan.

TABEL VIII

PENGUJIAN SPEECH RECOGNITION NUMERIK

\begin{tabular}{|c|c|}
\hline Pengucapan & Keterangan \\
\hline 1 & Valid \\
\hline 10 & Valid \\
\hline 100 & Valid \\
\hline 1000 & Valid \\
\hline
\end{tabular}

\section{F. Analisis Perbandingan hasil pengujian}

Pada game yang dibangun, terdapat fitur speech recognition sebagai salah satu metode menjawab soal-soal yang disediakan. Penggunaan fitur ini agar pemain yakni siswa-siswi SMPS YKPP Sungai Pakning dapat melatih kemampuan spelling menggunakan Bahasa Inggris dan sebagai tantangan yang menarik kepada anak. Pada game juga disediakan metode menjawab menggunakan tombol agar pemain tetap dapat memainkan game untuk berpikir induktif walaupun sedang berada di lingkungan yang tidak memungkinkan untuk menggunakan fitur deteksi suara. Pada permainan ini, tidak ada perbedaan perbandingan hasil ketika pemain bermain menggunakan metode menjawab apapun dikarenakan tidak ada perbedaan kesulitan soal yang diberikan namun hanya berbeda cara menjawab menggunakan deteksi suara dengan spelling Bahasa inggris dasar dan pilihan ganda.

\section{KESIMPULAN}

Game analysis training telah diujikan kepada peserta didik SMPS YKPP Sungai Pakning dan hasil pengujian menunjukkan tes yang dilakukan menggunakan metode Game mampu meningkatkan kemampuan berpikir induktif peserta didik sebesar 13,8\% pada form Intelligenz Structure Test dan 8,28\% pada form Inductive Reasoning Test. Berdasarkan data pengujian yang telah dilakukan, terbukti bahwa kemampuan berpikir induktif pada siswa dapat meningkat dengan hasil yang lebih baik daripada hasil pengujian konvensional (menggunakan kertas)

\section{UCAPAN TERIMA KASIH}

Terimakasih saya ucapkan untuk civitas SMPS YKPP Sungai Pakning atas kesempatannya untuk dijadikan studi kasus penelitian ini. Terima kasih kepada Politeknik Caltex Riau yang telah mendukung dan membantu penelitian saya hingga selesai.

\section{DAFTAR PUSTAKa}

[1] Teorema, J. T. (2017). TEOREMA. Analisis Kemampuan Berpikir nalar matematis serta kontribusinya terhadap prestasi belajar, 55 .

[2] Dra. Erni Yulial, S. P., \& Kasmawati, S. (2019, February). Wawancara Langsung Psikolog Klinis dan Guru Matematika. (H. Sasmita, Interviewer)

[3] Trisnadoli, A. (2015). Analisis Kebutuhan Kualitas Perangkat Lunak pada Software berbasis Mobile.

[4] Kuswardayan, dkk. (2016). Rancang Bangun Game Berhitung Spaceship dengan Pengendali Suara Menggunakan Speech Recognition Plugin pada Unity.

[5] Jaya, M., T., S., \& Puspitaningrum, D., \& Susilo, B. (2016). Penerapan speech recognition pada permainan teka-teki silang menggunakan metode Hidden Markov Model (HMM) berbasis desktop. Bengkulu: Universitas Bengkulu.

[6] Raymond. (2017). Pembangunan Game Memory Training terhadap Peningkatan Short Term Memory (STM) pada Anak SMP Menggunakan Speech Recognition (Studi Kasus: SMP Dharma Loka Pekanbaru).

[7] Adrian H. O. (2018). Pembangunan Game Analysis Training terhadap Peningkatan Kemampuan Analisa Soal pada Anak SMP Menggunakan Speech Recognition (Studi Kasus: SMP Metta Maitreya).

[8] Novayani, W. (2019). Game Genre untuk Permainan Pembelajaran Sejarah Berdasarkan Kebutuhan Pedagogi dan Learning Content. Jurnal Politeknik Caltex Riau, 54-63.

[9] Taufik Hidayat, M. M. (2018). Pengujian Sistem Informasi Pendaftaran dan Pembayaran Wisuda Online menggunakan Black Box Testing dengan Metode Equivalence Partitioning dan Boundary Value Analysis. Jurnal Teknik Informatika UNIS.

[10] Suryani, Y. E. (2018). Aplikasi Rasch Model dalam mengevaluasi Intelligenz Structure Test (IST). Psikohumaniora: Jurnal Penelitian Psikologi, 73 - 100

[11] Herdianto. (2012). Penerapan Speech Recognition Library Untuk Query Basis Data. Academia, 1-12. 